河道状態の影璄を考盧した洪水流の水位予測手法 Prediction of Flood Flow Profiles in River Courses with Luxuriant Vegetations

$\begin{array}{ll}\text { 東京工業大学工学部 } & \text { O福岡捷二 } \\ \text { 建設省土木研究所 } & \text { 高橋晃 藤田光一 渡辺明英 平林桂 坂野章 } \\ & \text { 森田克史 加賀谷均 林正男 長谷川賢市 }\end{array}$

Comprehensive field observations have been conducted to investigate characteristics of flood flow in the Hinuma River. The observations revealed that the water stage had irregular profiles due to longituidinal variation in the roughness consisting of luxuriant vegetations on the flood plains. The irregularity of flow profiles couldn't be reproduced well by the conventional method of non-uniform flow computation. In consideration of these facts, the method of flow computation was improved so that it would be possible to predict flow profiles in channels with luxuriant vegetations with more accuracy, compared with the existing methods.

Keywords : Flood flow, Non-uniform flow computation, Vegetation,Field observation, Hinuma River

1.はじめに

低水路河岸や高水敷には種々の植生が繁茂している場合があり，これらは洪水流に一定の影響を与える。 土木研究所では, 涸沼川における洪水観測施設 ${ }^{11}$ を用いた詳細な洪水流観測と観測区間についての大型模型 実験に基づいて，低水路河岸に繁茂した植生が低水路抵抗特性に与える影響を実証的に明らかにしてきだ2。 しかし, 流量データが充分ではなかったために, 低水路満杯規模以上の流量での検討を行なうことができな かった。本研究は, 欠測流量を水理的な方法で推定し, 水位が高水敷高を上回るというより一般的な水理条 件の下で高水敷表面の状態が洪水流に与える影響を明らかにし, その結果に基づいて, 植生繁茂等の河道状 態を考慮したより合理的な水位予測手法を開発しようとするあのである。

\title{
2. 河道状態と洪水流特性との関係
}

2. 1 洪水観測区間の河道状態

涸沼川は，一級河川那珂川の右支川であり，茨城県の中部に位置し， $446 \mathrm{~km}^{2}$ の流域面積と $65 \mathrm{~km}$ の流路延長 を有している。洪水観測の対象としたのは，涸沼川28.1 kmを中心とした長さ約700mの区間である。洪水観測 区間の平面図を図 1 に，代表地点の横断面図を図 2 に示す。この区間は，全巾約 $100 \mathrm{~m} ，$ 低水路巾約 $25 \mathrm{~m}$ の複 断面形状をしており, 平均河床勾配は約 $1 / 900$, 低水路河床材料はれき混じり砂となっている。低水路河岸 に護岸はなく，低水路河岸の一 部には篠竹・柳等が密生し, ま た高水敷上にも竹林・桑畑から なる樹木群が密生している場所 がある。本論文では，現在まで に観測された最む大きな洪水, すなわち1986年8月に起こった 台風 10 号による洪水 (以後 8 月 洪水之呼ぶ）のうち低水路渵杯 以上の場合の観測結果を対象に する。8月洪水は, 図2 に示す

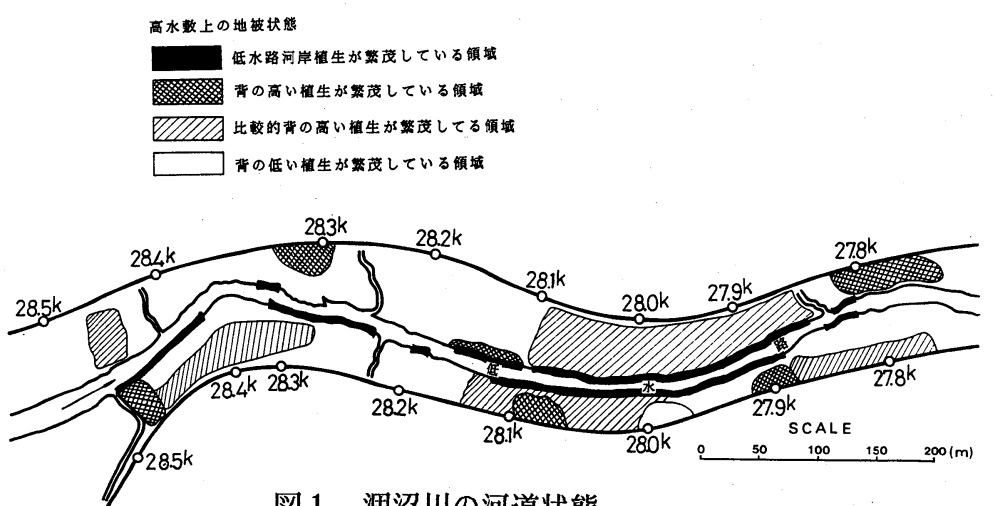

図 1 涸沼川の河道状態 
水位の時間変化からわかるように，堤防渵杯規模の洪水 であった。なお，観測内容及び観測施設の詳細について は，文献(1)，(2)に詳述されているので参照されたい。 2.2 洪水流の特性

8 月洪水についての各時刻の水位縦断図を図 3 に示す。敤 同図中には，左右岸高水敷高，洪水前後の河床高も合わ せて示されている。これらの図から以下のことがわかる。 水位縦断変化特性は, 洪水が低水路だけを流下している 場合と，水位が高水敷高以上になっている場合とで大き

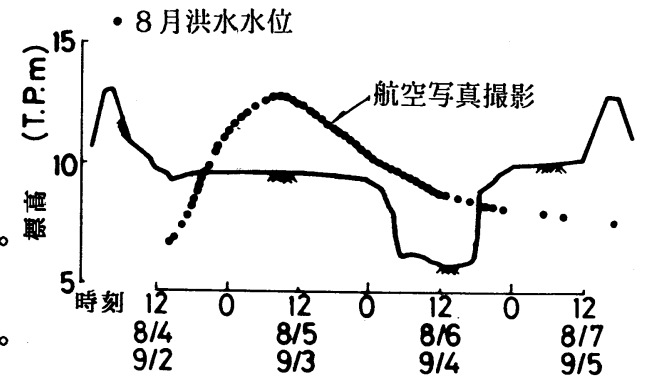

図2 $28.1 \mathrm{Km}$ 地点の横断図と水位の時間変化 く異なる。前者の場合には，小さな凹凸はあるすのの，全体として は滑らかな水位縦断形が現れているのに対して, 後者の場合には, 水位縦断形がより大きな凹凹を持つようになる。特に，28.1 Km地点 において上に凸のはっきりした頂点が現れ，この上下流で水面勾配 が大きく変化している。図 4 は, 水位がピーク水位より約 $1 \mathrm{~m}$ 程度 低い8月5日16:00に, 航空測量によって測定された表面流速の平面 分布である。図より, 高水敷の流速は場所によって大きく異なり, 流速が0に近い領域がところどころに現れている。これは, 図 1 に 示すように, 高水敷上のところどころに背の高い粗度要素があり, そのような場所では流速が大きく低減させられるためと考えられる。 以上のことは, 水位縦断形が, 堤防間距離の縦断的な変化の他に, 高水敷上の植生等に代表される河道状態の場所的な変化に影響を受 けていることを示している。したがって, 図 3 に示した水位縦断形 の凹凸を予測するためには, 高水敷上の植生等に代表される河道状 態の場所的な変化を水位予測に考慮する方法を検討する必要がある。

\section{3. 低水路満杯以上の流量の推定}

\section{1 流量推定の基本的な考元方}

前章に示した観測結果に基づいて水位予測手法の検討を行うに当 たっては，流量データが必要となる。しかし，8月洪水については， 当時の観測施設が未完成であったために, 水位が高水敷高以上の場 合の流量観測を欠測している。この例に見られるように，洪水デー 夕に関しては, 洪水観測自身の困難さのため, 全てのデータが揃う
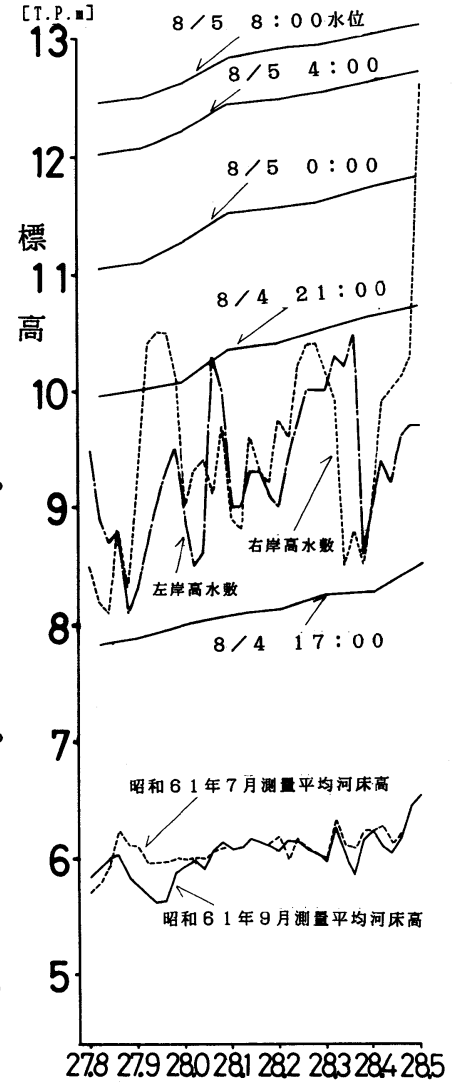

図 3 水位縦断図 ことを期待できない場合が多い。そ のような場合にも，データの不完全 な部分を何等かの方法で補い，得ら れた貴重なデータを生かすことは非 常に重要である。そこで，ここでは， 流量以外のデータから流量を推定す ることを試みる。推定に当たっては，

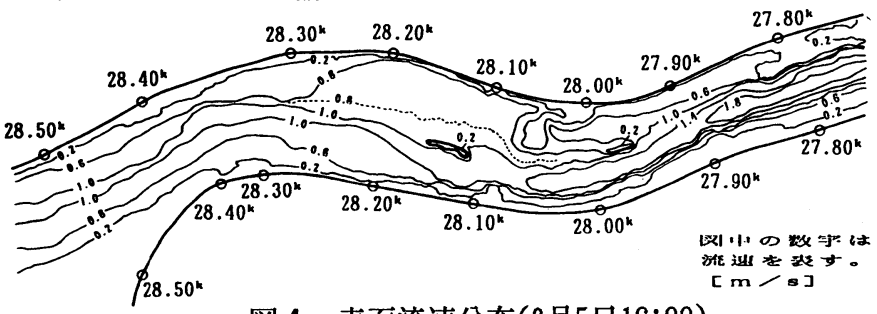

図 4 表面流速分布(8月5日 $16: 00)$

まず，縦断方向に比較的一椂な横断面形と河道状態を持つ区間を選び出し，その区間の高水敷と低水路の粗 度係数を, 表面流速分布とそれを測定した時刻の水位縦断変化から求める。得られた高水敷, 低水路それぞ れの粗度係数と各時刻の水位縦断変化から, 各時刻の流量を推定する。以下に, 具体的な方法を示す。 


\section{2 高水敷および低水路の粗度係数の推定}

涸沼川の高水敷は，図 1 に示したように，様々な地被状態から成っているが，28.10Km〜28.30Km区間では， 河道が比較的直線で高水敷上の植生むほぼ均一（水田）となっており，粗度係数が一様であると考えられる。 このことから, 表面流速の平面分布を用いた粗度係数の推定を28.10 28.30Km区間で行う。粗度係数の推定 は，低水路部之高水敷部とに分割して，それぞれ次に示すマニングの抵抗則により行う。

$$
\mathrm{n}=1 /(\alpha \mathrm{v}) \cdot \mathrm{R}^{2 / 3} \cdot \mathrm{I}_{\mathrm{e}}^{1 / 2}
$$

ここで, $\mathrm{n}$ : 粗度係数, $\alpha$ : 更正係数(断面平均流速と航空写真から得られる表面流速との比), $\mathrm{v}$ : 表面流 速の平面分布より求めた高水敷, 低水路領域それぞれの平均表面流速 $(\mathrm{m} / \mathrm{s}), \mathrm{I}_{\mathrm{e}}:$ エネルギー勾配, $\mathrm{R}: 2$ $8.2 \mathrm{Km}$ の径梁, である。 $\alpha$ の値については，まだ充分には明らかになっていないので，ここでは $\alpha=1.0 と し$

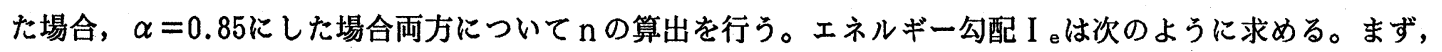
低水路については, 28.1 28.3km区間の中間である $28.2 \mathrm{~km}$ 地点の低水路表面流速と更正係数 $\alpha$ から低水路流 量 $\mathrm{Q}_{\mathrm{mc}}$ を求め, この流量が28.1, 28.3km地点の低水路流量に等しいと仮定して, これら 2 地点の速度水頭を 求める。得られた 2 地点の速度水頭の差と水位の差からエネルギー勾配 $\mathrm{I} \mathrm{e}$ を求める。高水敷については, 2 $8.10 \mathrm{Km} \sim 28.30 \mathrm{Km}$ にいて高水敷上の単位幅当りの流量が一定と仮定して次式より求める。

$$
I_{e}=I_{w}+\frac{(\alpha v)^{2}}{g h}\left(i_{b}-I_{w}\right)
$$

ここで, $h$ : 水深, $\mathrm{i}_{\mathrm{b}}$ : 河床勾配, $I_{\mathrm{w}}$ : 水面勾配, である。

以上に示した方法により推定した低水路, 高水敷の粗度係数を表 1 に示す。表より, 低水路の粗度係数が 大きく, 水田である高水敷上の粗度係数値と同じ程度の值を持つことがわかる。この原因として, 低水路河 岸の植生による流水減勢勃果 ${ }^{2}$ があげられる。しかし, 28.1〜28.3Km区間の低水路河岸植生が他の区間に比 較して少ないこと, 河岸植生の影響が充分現れている低水路満杯時のこの区間の低水路粗度係数が $0.035 \sim 0$. 040程度であり, 表 1 の值に比べかなり小さいことから, 河岸植生だけでは表 1 の大きな低水路粗度係数值 を説明することはできない。このことから, 流速の小さい高水敷上の流れと低水路の流れとの干渉効果が低 水路粗度係数を大きくしているすう一つの原因になっていると考えられる。低水路幅が全川幅に比較して非 常に小さく, 高水敷上の流れと低水路流れとの干渉による低水路流速低減効果が大きく現れる河道条件であ ることも，上記の推定を定性的に裏付けている。

表 1 粗度係数推定値

\section{3 流量の推定}

航空写真撮影時(5日16:00)の水位がピーク水位よ り $1 \mathrm{~m}$ 程度下がったものであり, 高水敷上で十分な 水梁を持っていることから，3．2で推定した粗度 係数は, 高水敷水深がある程度以上大きい場合に限 って他の時刻（水位）にむ適用できると仮定する。 流量の推定は, $28.10 \mathrm{Km}$ の実測水位を下流端水位と し，28.10Km〜28.30 Km区間で不等流計算を行い 28.3 0Kmの計算水位と実測水位が一致する流量を推定流 量とするという方法により行った。不等流計算は, 井田の方法により行った ${ }^{3)}$ 。この際必要となる高水 敷, 低水路それぞれの粗度係数には表 1 の值を与え た。推定した流量を図 5 に示す。推定した流量值は,

\begin{tabular}{|c|c|c|}
\hline 更正係数 & 低水路 & 高水数 \\
\hline 0.85 & 0.060 & 0.061 \\
\hline 1.0 & 0.050 & 0.052 \\
\hline
\end{tabular}

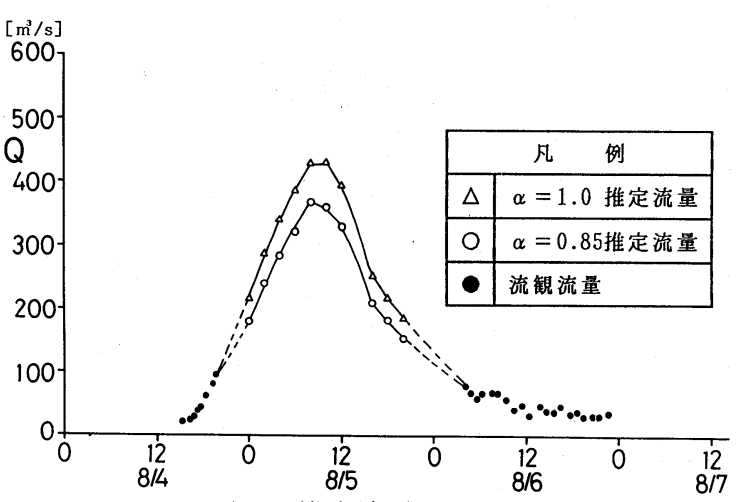

図 5 推定流量

観測されている低水路満杯以下の流量值と滑らかにつながる。この図より，8月洪水のピーク流量は $400 \mathrm{~m}^{3} /$ s前後であったと推定される。 
4. 高水敷上の河道状態を考慮した不等流計算法の 検討

4. 1 従来の計算法の問題点

本観測区間には，図 1 に示したように，高水敷上に 高さや密度の異なる粗度要素がある。背の高い粗度要 素がある部分はほとんど流速がないことが図4よりわ かる。このように, 実際の流速が非常に小さい領域を 河積に含めて計算すると計算水位が実測水位をあまり よく再現しないことは, 涸沼川の低水路内だけを流れ る洪水についての計算で確認されているが ${ }^{2)}$, ここで 対象としている広い高水敷を持つ河道の河道満杯規模 の洪水については, 実測水位と計算水位の縦断形の一 致度がさらに低下すると予想される。このことを定量 的に把握するため, 粗度要素による低流速域を死水域 としない従来の不等流計算によって水位計算を行った。 水位計算においては，3.2節で推定した $\mathrm{n}_{\mathrm{mo}}=0.050$ （ $\alpha=1.0$ を用いた推定值）が対象区間の低水路粗度係 数を代表していると考えて，この值を低水路粗度係数 に用い, 計算水位縦断が実測水位縦断と平均的に合う ようになるまで高水敷の粗度係数 $\mathrm{n}_{\mathrm{f}} \mathrm{p}$ を変化させ行な った。また, 計算で与えた流量は，3．3で推定した 流量のうち $\alpha=1.0$ を用いた不等流計算により推定した
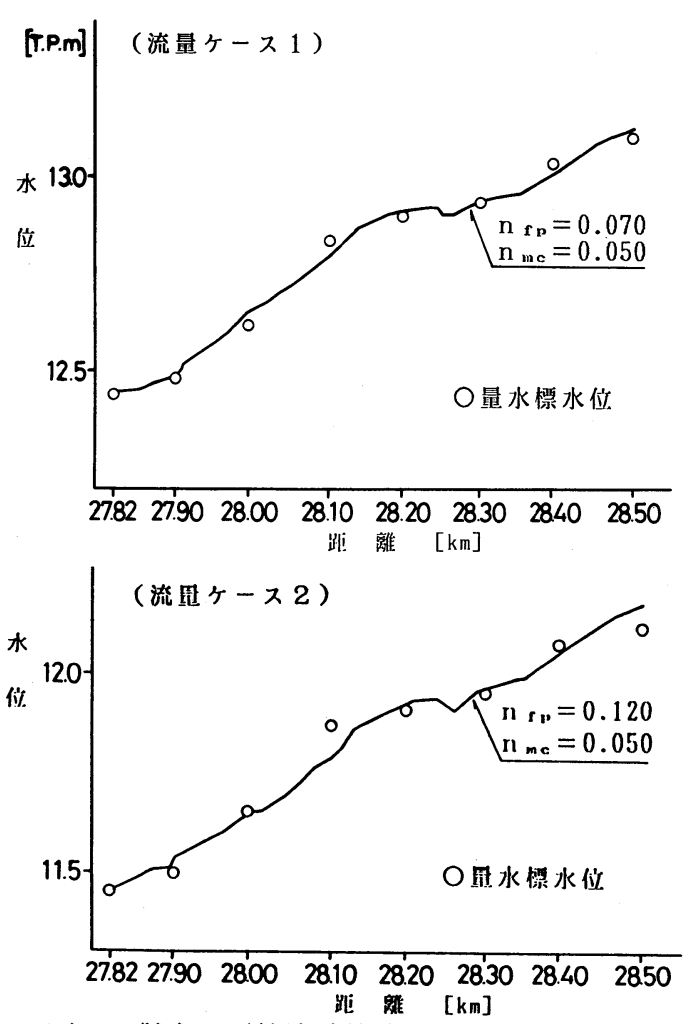

図6 従来の不等流計算法による計算水位と 実測水位との比較 むのを用いた。計算の対象とした流量は，ピーク水位にあたる8/5 8:00の $430 \mathrm{~m}^{3} / \mathrm{s}$ (流量ケース 1 )，ピー ク水位より $1 \mathrm{~m}$ 低い $8 / 516: 00$ Q $=250 \mathrm{~m}^{3} / \mathrm{s}$ （流量ケース 2) である。なお，水位計算には井田による不等流計 算法 ${ }^{3)}$ を採用した。逆算した水面形を図6に示す。これを見ると, 高水敷上に比較的高い粗度要素がある 27. $82^{\mathrm{k}} \sim 28.10^{\mathrm{k}}$ 区間で, 実績水位の水面勾配は他の区間のそれに比べてかなり大きくなっているが, 計算水位 の水面勾配をみると, いずれの流量ケースにおいても実績水面勾配に比べ小さくなっている。計算水位が平 均的に実績水位に合うような高水敷の粗度係数を見ると, 流量ケース 1 では $\mathrm{n}_{\mathrm{f}} \mathrm{p}=0.070$, 流量ケース 2 では $\mathrm{n}_{\mathrm{p}}=0.120$ となり, 流量によって $\mathrm{n}_{\mathrm{f}} \mathrm{p}$ を大幅に変える必要があることがわかる。また，この粗度係数値は実 態から考えて大きい。以上のことから，本観測対象区間のように背の高い粗度要素が比較的多くある河道へ の従来の計算法の適用が不適切となる場合があることが示された。

\section{2 不等流計算法の改良}

従来の計算法の問題点を解決するためには, 高水敷の表面状態の縦断変化を計算の中に組込み, 実態に合 わせて粗度係数を細かく変えなくても水面形を良く再現できるようにしなければならない。徉来の不等流計

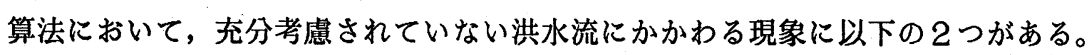

(1) 植生等の粗度要素を持つ高水敷上の低流速域とその周囲の高流速域との流体混合による抵抗增加 ${ }^{2) ， 4)}$

(2) 背の高い粗度要素による低流速域の存在

涸沼川では，3．2であ触れたように，上記11の現象の影響が最む顕著に現われるのが低水路流れである。 しかし, 本解析では, 実測值より求めた低水路粗度係数値を用いており，この值に流体混合による抵抗增加 が含まれている。したがって，一般的には11の効果を考虑する必要があるむのの，本解析では(1)の効果を考 慮しないむのとする。一方, (2)の現象は, 2章で示したように, 涸沼川観湘対象区間では大きな影響を洪水 流に与えるので, 以下ではこの点について計算法の検討を行う。(2)の現象は, 植生などの背の高い粗度要素 
による低流速域を死水域として河積 から除外することにより，不等流計 算の中で考慮できると考えられる2)。 しかし, 高水敷上の背の高い粗度要 素を考虑した計算を実際に行うにあ たっては，2つの問題が生じる。1 つは, 死水領域と考える粗度要素の 高さの設定法である。一部の植生は 洪水時にしなったり, 植生の密度が

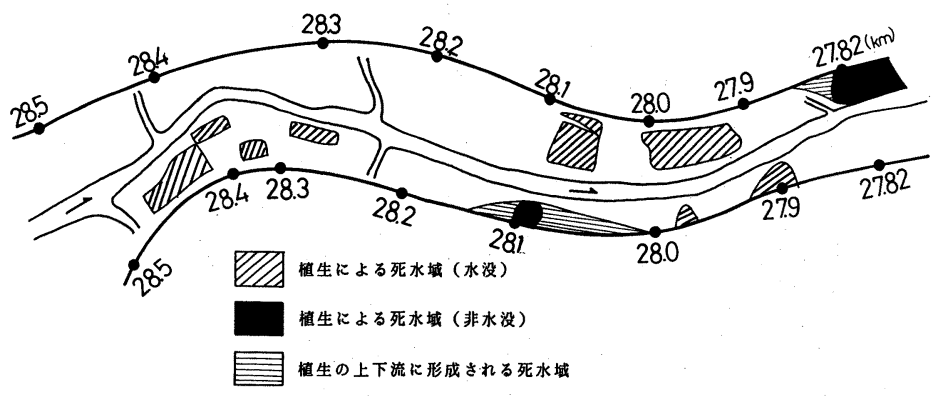

図7 改良した不等流計算において死水域として报う領域 小さい場合には植生内をかなりの流量が透過することが起こり得るので, 平水時に植生繁茂領域として測量 された部分をすべて河積から除外すると，植生の水理的影響を過大に評価してしまうことになる。したがっ て, 死水域として河積から除外すべき領域と, 河積に入れるべき領域を, 植生などの粗度要素の形態から判 定することが必要となる。本解析では，次のような考え方に基づいて，死水域設定についての判定を行った。 a ）草類から成る粗度要素の領域は死水域とせず, その流水抵抗を粗度係数により表現する。これは, 草の 場合，幹が柔らかく洪水中にかなりしなっていると考えられるからである。

b ) 樹木群（竹も含む）から成る粗度要素は, 原則として死水域とする。これは, 樹木類の場合, 幹, 枝が 堅く, 洪水流の中でも容易にはたわまないため, 流水中において明確な死水域が形成されると考元たか らである。ただし，樹木が茂っている場合でも，その密度が小さく，樹木群領域全体が死水域になる と考元られない場合には，死水域としない。また，柳のように樹木であっても流水により大きくしなる 場合には，しなりによる死水域の現象を考慮する。

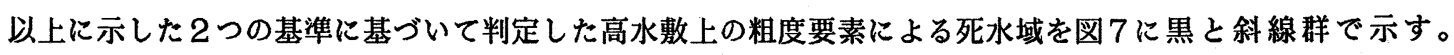

ところで，図 $7 に$ 示すように死水域を設定して不等流計算を行うと，河積が大きくない断面では，死水域 前後で河積が急激に変化するため, 計算水位に, 実際には現れない大きな凹凸が現れる。これは, 死水域を 形成する粗度要素の上下流（特に下流）に生じる死水域を計算に考慮していないことに起因する。そこで, 図 7 の横線群に示すように，粗度要素による直接的な死水域の上下流に形成される死水域を設定し，これら を合せた領域を計算で考慮する死水域とした。粗度要素の上下流の死水域は，その外縁と主流とのなす角度 が上流については2 6 度, 下流については 5 度となるように設定した。なお, これらの死水域の設定は, 水 梁よりむ背の高い粗度要素がある領域に限定し, 水没する粗度要素に関しては行わなかった。これは, 水没 する粗度要素についても上下流の死水域を考慮すると, 図8に示すように, 計算水位が実測水位よりむ高く なり，これを無理に実測值まで下げるためには極端 に小さい高水敷粗度係数值を用いなければならず, 計算の物理性を失うからである。この原因について は次のように考えられる。水没する粗度要素の上下 流に形成される死水域は, 粗度要素上を通る流れが あるために，粗度要素の領域から離れるにしたがっ てすばやくその高さを減ずるのに対して，水没しな い粗度要素の上下流に形成される死水域は, 主流の 影響を側方からしか受けないため, 粗度要素から離 れることによる死水域の滅少の度合いが小さい。こ のため, 水没の有無およびその程度によって, 粗度 要素の領域の上下流に形成される死水域の大きさが 大きく異なり，水没水深がある程度以上大きくなる

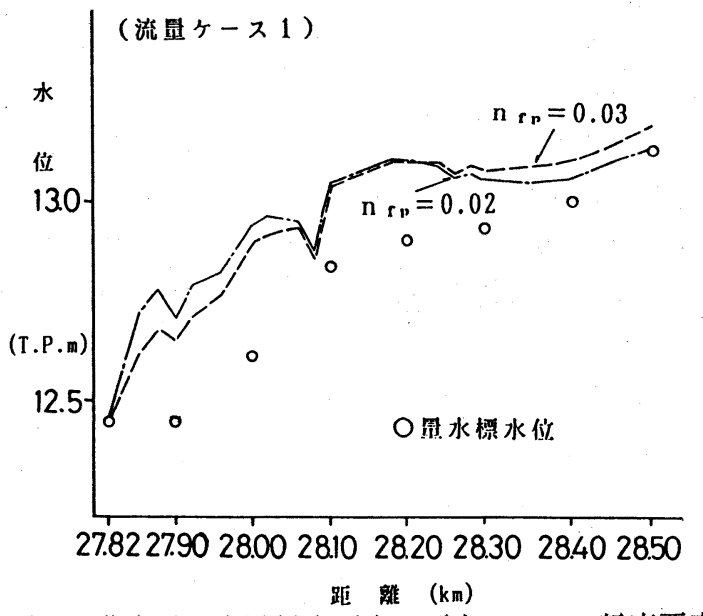

図8 非水没, 水没粗度要素の両方について粗度要素 の上下流に死水域を設定した場合の計算水位 
と，その上下流の死水域は計算上無視できる大きさ となる。

4. 3 改良した計算法による実測水位の再現性

図7のように設定した断面条件を用い，4，1 と 同じ流量ヶースについて，同じ方法を用いて不等流 計算を行い，最む計算水位と実測水位が平均的に合 う高水敷粗度係数 $\mathrm{n}_{\mathrm{f}} \mathrm{p}$ の下での計算水位を求めた。 低水路粗度係数 $\mathrm{n}_{\mathrm{m}}$ には 4.1 と同様0.05を用いた。 図 9 に計算結果を示す。図より, 植生などの粗度要 素による死水域を多く設定した27.82〜28.10Km区間 の再現性が，死水域を設定しない場合に比べてかな り良くなっていることがわかる。28.08 $\mathrm{km}$ 地点の水 位が上下流に比べ小さくなっているのは, この付近 に大きな死水域があり河積が小さくなっているから である。また, 計算で用いた高水敷粗度係数值は, 0.030 0.045であり，死水域を設定しない場合に比 較して小さくなり, 変動の幅む小さくなっている。 このことは, 流量の大きさによって粗度係数を大き く変えなくてあ水位予測が可能であることを意味し ている。以上から, 背の高い粗度要素が比較的多く ある河道についても, 改良した不等流計算法によっ て精度の高い水位予測を合理的に行なうことが可能 であることが示された。なお，本計算のように 4 . 2の11に示した効果を含んだ粗度係数値が得られて いない場合には, 洪水流の横断方向流速差の存在に ともなう付加的抵抗を考慮した計算を行なう必要がある ${ }^{4)}$ 。
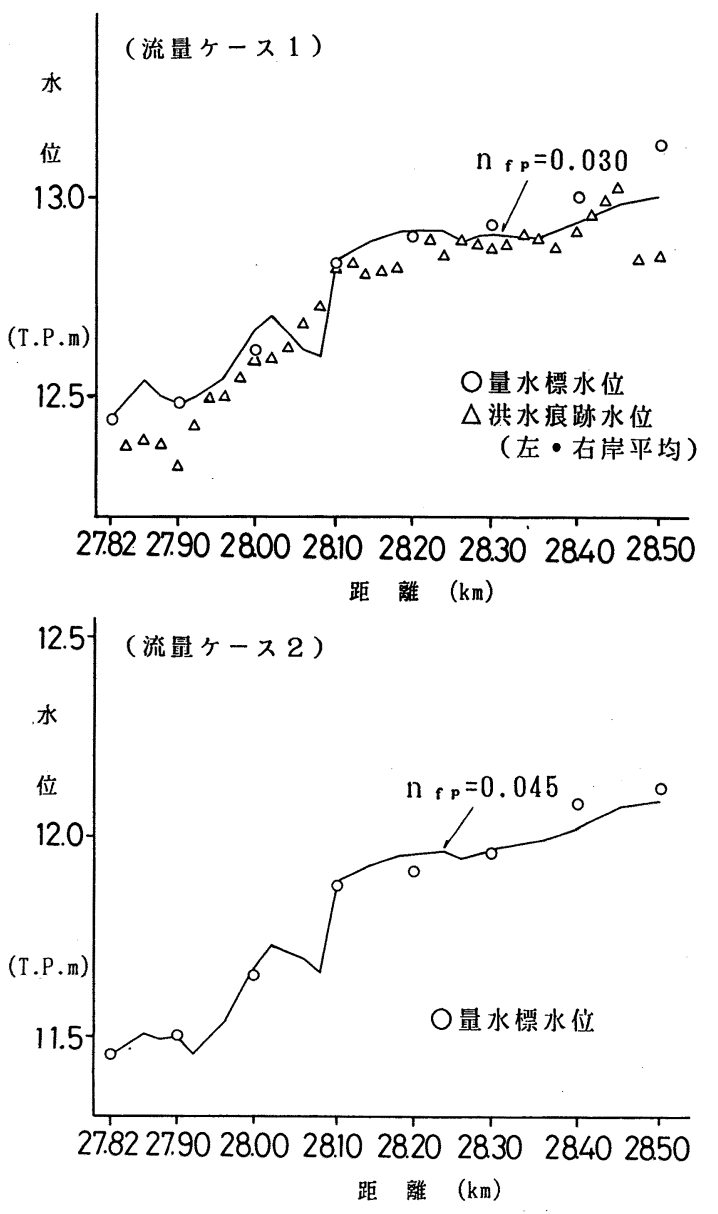

図9 改良した計算法による計算水位と 実測水位との比較

\section{5.おわりに}

改良した不等流計算法においては, 植生等の粗度要素の形状を把握し, それを従来の不等流計算法の断面 形の設定に組込むことによって，機械的に植生等の河道状態の縦断的な変化特性を考慮することができる。 植生等の粗度要素の形状は, 航空写真測量によって, 現地調查によらず簡単に求めることができる5 。した がって, 本手法を他のさらに規模の大きい実河川に適用することは充分可能であり, 本手法は害用的な不等 流計算法になりうると考えられる。今後, 用いるべき高水敷粗度係数值の決定法の検討, 死水域設定法の判 断基準の明確化を種々の状況における実測值と計算值の比較を通して行なうことにより，ここで提案した方 法を植生が繁茂した河道の一般的な水位予測手法として確立することができると考えられる。

\section{参考文献}

1)福岡捷二ほか：1986年8月洪水による涸沼川の河床変動, 第31回水理講演会論文集, 1987 .

2)福岡捷二ほか：涸沼川におりる洪水流の特性, 第32回水理講演会論文集, 1988 .

3)建設省河川局監修：改訂建設省河川砂防技術基準(案)調查編，52年改訂，山海堂，1977.

4)福岡捷二・藤田光一 : 洪水流の横断方向流速差がもたらす付加的抵抗の評価, 第33回水理講演会論文集, 1989.

5)福岡・藤田・荒木 : 洪水解析精度向上のための航空写真撮影法の改良, 第32回水理講演会論文集, 1988. 